\title{
Lipids, proteins, phenolic composition, antioxidant and antibacterial activities of seeds of peanuts (Arachis hypogaea I) cultivated in Tunisia
}

\author{
Khaled Sebeia ${ }^{*}$, Asma Gnoumaa, Wahid Herchia, Faouzi Sakouhia, Sadok Boukhchina ${ }^{a}$ \\ a Laboratoire de Biochimie des Lipides et Interactions avec les Macromolécules, Faculté des Sciences de Tunis, Université de Tunis-El-Manar. Tunisia.
}

\begin{abstract}
Fatty acid composition of peanut seed oil in four varieties cultivated in Tunisia showed that linoleic (C18:2), oleic (C18:1) and palmitic (C16) acids account for more than $84 \%$ for Chounfakhi and Massriya and for more than $85 \%$ of the total fatty acids of Trabilsia and Sinya seed oil respectively. Seed oil contents were significantly different $(P \leq 0.05)$ and did not exceed $48 \%$. The study of total phenolics revealed that Chounfakhi contained more total phenolics (2.1 mg GAE/g DW), followed by the Massriya and Sinya cultivars (1.35 mg GAE/g DW for each); Trabilsia presented the lowest total phenolic content with $1 \mathrm{mg} \mathrm{GAE} / \mathrm{g}$ DW. Considerable antiradical ability was found, especially in the Trabilsia peanut seed cultivar (IC50 $=1550 \mu \mathrm{g} / \mathrm{ml}$ ), the Massriya and Sinya cultivars had, respectively, $720 \mathrm{and} 820 \mathrm{mg} / \mathrm{ml} \mathrm{IC50}$. In the Massriya variety the sterol fraction showed antibacterial activity against Listeria ivanovii, Listeria inocua, Pseudomonas aeruginosa, Staphylococus aureus, Enterococcus hirae and Bacillus cereus.
\end{abstract}

Keywords: Arachis hypogea; oil; sterols; phenols; antioxidant activity; antibacterial activity.

\section{INTRODUCTION}

Peanuts (Arachis hypogaea L.) are grown in almost all tropical and sub-tropical countries; the most important producers are India, China, USA and West Africa (Krishnappa et al., 1999 ; Bhatti et al., 2010,). Peanuts, known in Tunisia as "cacawya", are mainly cultivated in the Cap Bon region (NE Tunisia) as well as in Nefza (NW) and Kairouan (Center) (Bornat, 2006). Compared to other oleaginous seeds, peanut seeds have a low amount of phospholipids (0.65 to $1.35 \%), 0.8 \%$ unsaponifiable (Yoshida et al., 2005), and 44 to $56 \%$ oil with a fatty acid composition mainly represented by oleic (37.94 to $41.90 \%)$, linoleic $(34.59$ to $37.51 \%)$, palmitic (12.22 to $13.30 \%)$, stearic (3.17 to $3.67 \%)$ and arachidic (1.63 to $1.85 \%$ ) acids (Berry, 1982; Kaya et al., 2009). The total fatty acid composition was $10.44 \%$ and $33.51 \%$ for saturated and unsaturated fatty acids, respectively; the most abundant fatty acids of groundnut seed oil were oleic (C18:1), linoleic (C18:2) and palmitic (C 16:0), which together composed about $88.35 \%$ of the total fatty acids (Ingale and Shrivastava, 2011). This food is made up $22-30 \%$ protein, thus being an excellent source of energy $(564 \mathrm{kcal} / 100 \mathrm{~g})$; defatted peanut flour is a byproduct of peanut processing, which contains $47-55 \%$ proteins with high nutritional value (Yu et al., 2007). The main proteins are two globulins, arachine and conarchine, that represent at least $95 \%$ of the total seed proteins (Yoshida et al., 1995; Andersen et al.,1998; Han et al., 2009). Phytosterols and triterpenes make up the greatest proportion of the unsaponifiable components of vegetable oils (Azadmard-Damirchi et al., 2005); they are considered to have anti-inflammatory, anti-bacterial, antiartherosclerotic, antioxidative (Lagarda et al., 2006), antiulcerative and antitumor properties in humans (Moreau et al., 2002), as well as contributing to the oxidative and thermal stability and shelf-life of vegetable oils (Beveridge et al., 2002;
Przybylski and Eskin, 2006, Alvarenga and Esteban, 2005). Peanut seeds have high nutritional and commercial value due to their protein, fatty acid, carbohydrate and fiber content, as well as vitamins, calcium, and phosphorous. Peanut oil is used in cooking and is also employed in the manufacture of margarines, cosmetics, pharmaceuticals and surfactants (Plessis and Steiman, 2004; Schirack et al., 2006; Nakai et al., 2008; Rodriguez et al., 2011).

The aim of this study was to analyze antioxidant activity and lipid, fatty acid, protein and phenolic composition in four groundnut varieties cultivated in Tunisia, as well as to test these compounds for antibacterial activity against reference strains.

\section{MATERIAL AND METHODS}

\subsection{Plant material}

The four groundnut varieties used in this study were Massriya, Sinya, Chounfakhi and Trabilsia. Their seeds were provided by the CRDA of Nabeul (NE Tunisia).

\subsection{Determination of oil content}

Oil content was determined by extracting dry material of peanut with petroleum ether using a Soxhlet apparatus $\left(4 \mathrm{~h} / 42{ }^{\circ} \mathrm{C}\right)$ (Harwood, 1984). The extract was dried in a rotary evaporator and the oil content was determined as the difference in weight between a dried peanut sample before and after extraction (AOCS, 1989).

\subsection{Saponification and TLC analysis}

The unsaponifiable fraction of lipids was determined by saponifying $5 \mathrm{~g}$ of oil mixed with both $200 \mu \mathrm{l} \alpha$-cholestanol 
and an ethanolic $\mathrm{KOH} 12 \%$ solution; the mixture was heated at $60{ }^{\circ} \mathrm{C}$ for $1.30 \mathrm{~h}$. The unsaponifiable matter was extracted, washed, dried over anhydrous $\mathrm{Na}_{2} \mathrm{SO}_{4}$ and evaporated to dryness using $\mathrm{N}_{2}$. The unsaponifiable matter was separated into subfractions on preparative silica gel thin-layer plates (silica gel 60G F254) using one-dimensional TLC with hexane-diethyl ether $(6: 4, \mathrm{v} / \mathrm{v})$ as the developing solvent. The unsaponifiable fraction diluted in chloroform was applied on the silica gel plates. After developing, the plate was sprayed with 2,7-dichlorofluorescein and viewed under UV light.

\subsection{GC-FID Fatty acids methyl ester analysis}

Fatty acids were methylated using the method of Metcalfe et al. (1966) modified by Lechevallier (1966). Methyl esters were analyzed with a gas chromatography-flame ionization detector (GC-FID) using an HP 4890 chromatograph equipped with a flame ionization detector (FID) on a capillary column coated with supelcowaxTM 10 (30 m length, $0.25 \mathrm{id}, 0.2 \mathrm{~mm}$ film thickness). Temperatures of the column, detector and injector were 200,250 and $260{ }^{\circ} \mathrm{C}$, respectively.

\subsection{SDS-PAGE of proteins}

Defatted peanut seeds (100 mg) were successively extracted with $1 \mathrm{ml}$ distilled water, $1 \mathrm{ml} 5.0 \mathrm{M} \mathrm{NaCl}, 1 \mathrm{ml}$ absolute ethanol, and $1 \mathrm{ml} 0.2 \mathrm{M}$ phosphate buffer $(\mathrm{pH} 8.0)$ for the extraction of the albumin, globulin, prolamin and glutelin, respectively. Each extraction was shaken for $20 \mathrm{~min}$ in an Eppendorf tube and centrifuged at $10,000 \mathrm{~g}$ for $6 \mathrm{~min}$. Protein fraction assays were performed following Bradford's method (1976). Sodium dodecyl sulfate-polyacrylamide gel electrophoresis (SDS-PAGE) was performed in a discontinuous buffered system according to the method of Laemmli (1970), using $12 \%$ separating gel and 3\% stacking gel.

\subsection{RP-HPLC phenol analysis}

Colorimetric quantification of total phenolics was determined as described by Dewanto et al., (2002). All samples were analyzed in three replicates.

Phenolic compound analysis was carried out using a liquid chromatography RP-HPLC coupled with a UV-vis multiwavelength Waters 996 Photoperiod Array Detector: $190-400 \mathrm{~nm}$. The separation was carried out in a $250 \times 4.6-\mathrm{mm}$, LD 5- $\mu \mathrm{m}$ symmetry shield C18 reversed phase column. The mobile phase consisted of acetonitrile (solvent A) and water $(80: 20 \mathrm{v} / \mathrm{v})$ with $1 \%$ formic acid (solvent B). The flow rate was kept at $1 \mathrm{ml} / \mathrm{min}$. The injection volume was $20 \mu \mathrm{l}$ and peaks were monitored at $275 \mathrm{~nm}$. Peaks were identified by congruent retention times compared to standards. Analyses were performed in triplicate.

\subsection{DPPH radical-scavenging activity}

The DPPH-quenching ability of plant extracts was measured according to Hanato et al. (1988). The ability to scavenge the $\mathrm{DPPH}$ radical was calculated using the following equation: (1) DPPH-scavenging effect $(\%)=[(\mathrm{A} 0-\mathrm{A} 1) / \mathrm{A} 0] \times 100$; where A0 is the absorbance of the control at $30 \mathrm{~min}$ and A1 is the absorbance of the sample at $30 \mathrm{~min}$. All samples were analyzed in three replicates.

\subsection{Antibacterial activity detection}

The fractions of lipids and proteins were individually tested against a large panel of microorganisms including Staphylococcus aureus (ATCC 6539), Pseudomonas aeruginosa (ATCC 15442), Escherichia coli (ATCC 25922), Enterococcus hirae ATCC10541, Listeria ivanovii and L. inocua (RBL 30 and RBL 29 respectively), Bacillus subtilis and B. cereus (168 and ATCC11778 respectively). All strains were obtained from the Institut Pasteur de Tunis. The bacteriological agar was from Biokar Diagnostics (Beauvais, France). Nutrient broth (NB) was from Difco (Becton Dickinson, Le Pont de Claix, France). All the other media used in this study were manufactured by Biorad (Marnes-La Coquette, France) and Merck. Antibacterial activity is revealed by growth inhibition in the test strain, observed in solid medium. In the present study we used the well diffusion method described by Perez et al. (1990).

\subsection{Statistical analysis}

The data (three replicates) were statistically evaluated using the JMP SAS version 12.6 software (Statistical Analysis System). (SAS, Institute INC, Box 8000, Cary, North Carolina 27511, USA).

\section{RESULTS AND DISCUSSION}

\subsection{Physiochemical characteristics:}

The average compositions of the four peanut seed varieties are shown in Table 1 . It shows significantly different oil contents $(P \leq 0.05)$ which were very high in Chounfakhi and Sinya (about 48\%), whereas in Trabilsia and Massriya they were slightly lower (45 and $46 \%$, respectively). These differences were probably due to the different origins of the four varieties, the environmental conditions they were subjected to and/ or year effect. For 1000-seed weight Trabilsia exhibited the lowest mean, but this showed no effect on its oil content. However, differences between the four varieties were not statistically significant $(P>0.05)$. Similarly, no significant differences were found in moisture. The values the of acid index were significantly different $(P \leq 0.05)$ in these groundnut varieties. Trabilsia and Massriya showed the highest values, which shows that their oils contain a lot of free fatty acids and are therefore of low quality. This may be due to the fact that seeds used in this work were not freshly harvested or were not well stored. Chounfakhi and Sinya, however, showed acid indexes which conform to the international norms of codex alimentarius.

Total unsaponifiable content did not exceed $1 \%$ in the four groundnut varieties and varietal differences were not statistically $(P \leq 0.05)$ significant (Table 1$)$. In the literature it was reported that unsaponifiable contents did not exceed $2 \%$ in oil seeds such as those of rapeseed and linseed (Sebei, 2005; Sebei et al., 2007).

\subsection{Biochemical composition:}

Protein composition: The four groundnut varieties exhibited relatively low protein content $(7-12 \%)$; the highest were found in Chounfakhi and Massriya (Table 1). In addition, differences between all varieties were statistically significant $(P \leq 0.05)$. 
In general, protein content in groundnut seeds is around 2030\% (Andersen et al., 1998). The local variety Chounfakhi can produce an appreciable quantity of protein, which encourages its cultivation in regions where it can adapt to climatic and edaphic conditions. Compared to other plant proteins, especially commercial soy protein isolate, the functional properties of peanut proteins were much poorer, which might greatly limit the application of peanut proteins in many food formulations (Liu et al., 2012). Using adequate buffers, we isolated all protein classes in seeds of the four varieties and found that they were almost totally composed of globulins $(95 \%)$, albumins, prolamins, and glutelins being with negligible contents (Table 1$)$. No significant $(P \leq 0.05)$ difference was found in the content of each protein class between the four varieties.

SDS-PAGE of total proteins and their fractions: This qualitative study was performed in SDS-PAGE. Figure 1 illustrates the electrophoretic profiles of total proteins in the four groundnut varieties. It does not reveal marked varietal differences. The major proteins belong to type A, represented with bands with molecular weight (MW) varying between 100 and $50 \mathrm{KDa}$ (high MW), type B (medium MW, from 35 to $25 \mathrm{KDa}$ ), types $\mathrm{C}$ and $\mathrm{D}$ (MW from 15 to $12 \mathrm{KDa}$ ), and type E (low MW, less than $10 \mathrm{KDa}$ ). According to Figure 2, which represents globulin electrophoretic profiles in the four groundnut varieties, there were four major bands: Band A (proteins with MW between 50 and $35 \mathrm{KDa}$ ), Band B (proteins with MW around $25 \mathrm{KDa}$ ), Band $\mathrm{C}$ (proteins with medium MW between 15 and $25 \mathrm{KDa}$ ), and Band D (proteins with low MW (around $10 \mathrm{KDa}$ ).

Fatty acid composition: Fatty acid composition of peanut seed oil is given in Table 2, which shows that linoleic (C18:2), oleic (C18:1) and palmitic (C16) acids accounted for more than $84 \%$ for Chounfakhi and Massriya and for more than $85 \%$ of the total fatty acids in Trabilsia and Sinya seed oil, respectively. This study shows that the oils of Tunisian peanut varieties contained oleic and linoleic acids at relatively high levels $32.63-39.65 \%, 27.16-41.38 \%, 30.31-41.85 \%$ and $32.12-$
$40.06 \%$ respectively for the Chounfakhi, Trabilsia, Sinya and Massriya varieties. Saturated fatty acids (SFA) accounted for $19.93 \%, 26.04 \%, 22.03$ and 20.67 of total fatty acids for Chounfakhi, Trabilsia, Sinya and Massriya, respectively. The main saturated normal chain fatty acids were myristic, palmitic, stearic, behenic and arachidic acid. The ratio of unsaturated to saturated fatty acids was 4.01 in Chounfakhi, $2.84 \%$ in Trabilsia, 3.53 in Sinya and 3.83 in Massriya. According to Ingale and Shrivastava (2011), the total fatty acid composition of peanut seeds was 10.44 and $33.51 \%$ for saturated and unsaturated fatty acids, respectively. The most abundant fatty acids of groundnut seed oil were oleic (C18:1), linoleic (C18:2) and palmitic (C16:0), which together composed about $88.35 \%$ of the total fatty acids. The most abundant saturated fatty acid in groundnut seed oil was palmitic acid (6.20 percent); the main unsaturated fatty acids were oleic acid $(16.28 \%)$ and linoleic acid $(16.35 \%)$.The source of variability may be genetic (plant cultivar, variety grown), seed quality (maturity, harvest-caused damage and handling/ storage conditions), oil processing variables, or accuracy of detection, lipid extraction method and quantitative techniques (Rodrigues and et al., 2011).

This preliminary study shows that peanut seed oils contain high relative percentages of linoleic acid (C18:2 w6). Potential effects of linoleic acid on health include anticarcinogenic, antiatherogenic and antidiabetogenic modulating properties; it has also attracted interest in the scientific community because of its potential effects on body composition, reducing body fat mass and increasing lean mass (Hernandez-Diaz et al., 2010). To enhance peanut seed oil, it was investigated as an alternative source for the production of a biodiesel fuel (Kaya and et al., 2009). The maximum oil to ester conversion was $89 \%$ and the viscosity of biodiesel oil is nearer to that of petroleum diesel; the calorific value is about $6 \%$ less than that of diesel.

Phenol analysis and antioxidant activities: The total phenolics, expressed as mg GAE/g dry peanut seeds per cultivar, are presented in Table 3. Chounfakhi contained the most total

\section{TABLE 1}

Physiochemical characteristics of four Tunisian peanut seed cultivars (Mean values, $n=3$ )

\begin{tabular}{lcccc}
\hline & Chounfakhi & Trabilsia & Sinya & Massriya \\
\hline Moisture (\%) & $8.48 \pm 0.54$ & $7.38 \pm 0.42$ & $7.74 \pm 0.31$ & $7.3 \pm 0.4$ \\
WTS (g) & $765 \pm 10.2$ & $334 \pm 11,3$ & $702 \pm 12.4$ & $885 \pm 13.41$ \\
Oil content (g.100 g-1) & $48.53 \pm 1.9$ & $45.32 \pm 1.1$ & $48.08 \pm 1.7$ & $46.38 \pm 1.5$ \\
Index acid & $1.68 \pm 0.05$ & $3.92 \pm 0.12$ & $2.24 \pm 0.09$ & $3.36 \pm 0.1$ \\
Unsaponifiables (\%) & $1.1 \pm 0.07$ & $0.74 \pm 0.02$ & $0.55 \pm 0.03$ & $0.98 \pm 0.04$ \\
Total Proteins & $120 \pm 1.32$ & $68 \pm 0.81$ & $105 \pm 1.27$ & $86 \pm 1.09$ \\
(mg.g - $\left.^{-1} \mathrm{FW}\right)$ & $95 \%$ & $94 \%$ & $95 \%$ & $95 \%$ \\
Globulins $(\%)$ & $3 \%$ & $3 \%$ & $2 \%$ & $3 \%$ \\
Albumins (\%) & $1,5 \%$ & $1,5 \%$ & $2 \%$ & $1 \%$ \\
Prolamines $(\%)$ & $0,5 \%$ & $1,5 \%$ & $1 \%$ & $1 \%$ \\
Glutelines $(\%)$ & & & & \\
\hline
\end{tabular}

WTS: Weight of one thousand seeds 
phenolics (2.1 mg GAE/g DW), followed by the Massriya and Sinya cultivars (1.35 mg GAE/g DW for each), Trabilsia presented the least total phenolic content, with $1 \mathrm{mg}$ GAE/g DW. As found for total phenolic content, antioxidant activity showed differences between peanut seed varieties.

The HPLC study of Arachis hypogea seed extract identified 6 phenolic compounds in the Massriya cultivar, with rutin trihydrate and p-coumaric acid as the major compounds
(6.79\% and $6.35 \%$, respectively), 7 phenolic compounds in the Sinya cultivar with p-coumaric acid as the major compound $(4.03 \%), 8$ phenolic compounds in the Chounfakhi cultivar with p-coumaric acid as the major compound (4.87\%) and 5 phenolic compounds in Trabilsia cultivar with rutin trihydrate as the major compound $(4.52 \%)$. The compounds identified were (Table 4): caffeic acid, dihydroxyphenylacetic acid, syringic acid, p-coumaric acid, rutin trihydrate,

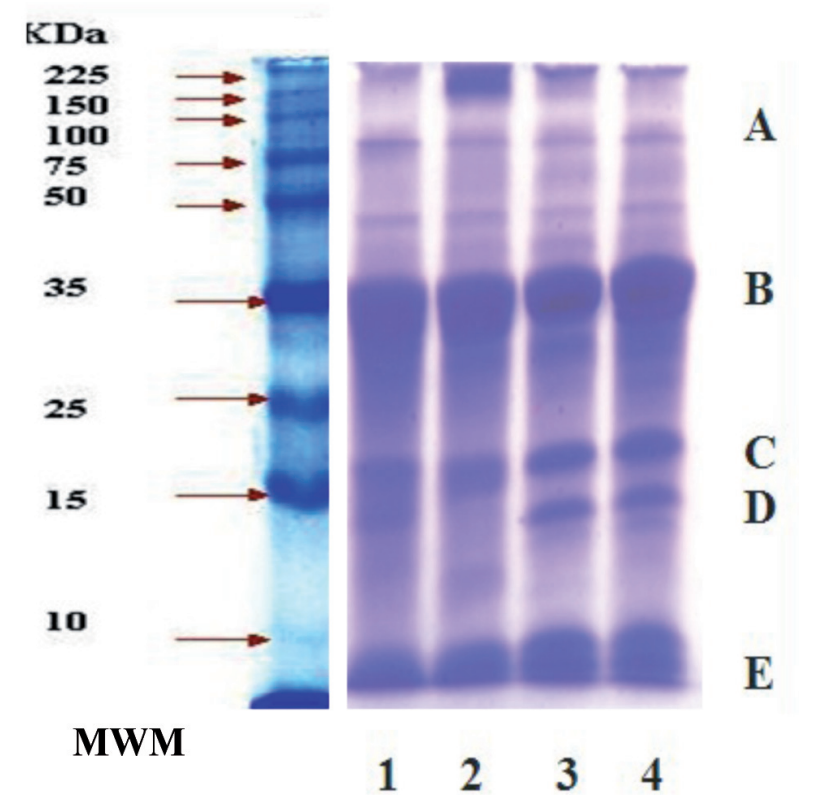

Figure 1: SDS-PAGE profile of total proteins extracted from different peanut cultivars. MWM: Molecular weight marker (KDa); 1: Chounfakhi; 2: Trabilsia; 3: Sinya; 4: Massriya

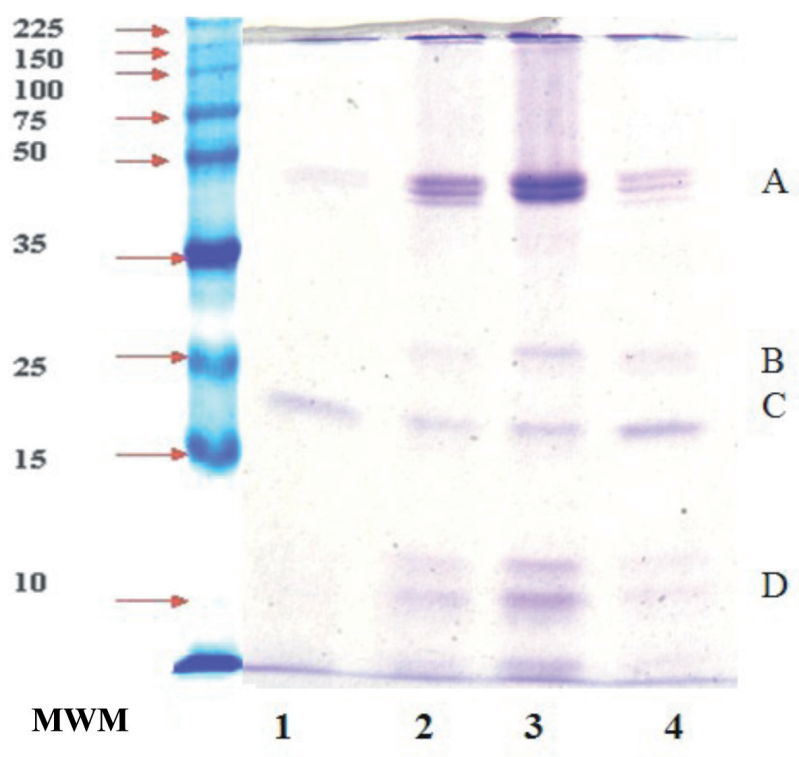

Figure 2: SDS-PAGE profile of globulins extracted from different peanut cultivars:

MWM: Molecular weight marker (KDa); 1: Chounfakhi; 2: Trabilsia; 3: Sinya; 4: Massriya

TABLE 2

Fatty acid compositions (\% of total fatty acid) of peanut cultivars

\begin{tabular}{lcccc}
\hline Fatty acids & Chounfakhi & Trabilsia & Sinya & Massriya \\
\hline C14 & 1.19 & 0.77 & 0.79 & 1.56 \\
C16 & 12.11 & 17.45 & 13.34 & 11.89 \\
C16:1 & 3.43 & 1.93 & 2.15 & 3.17 \\
C18 & 4.01 & 4.12 & 4.1 & 4.59 \\
C18:1 & 32.63 & 27.16 & 30.31 & 32.12 \\
C18:2 & 39.65 & 41.38 & 41.85 & 40.06 \\
C18:3( $\left.w_{3}\right)$ & 1.63 & 1.27 & 1.31 & 1.41 \\
C22 & 0.58 & 1.1 & 0.98 & 0.39 \\
C22:1 & 2.73 & 2.22 & 2.35 & 2.57 \\
C24 & 2.04 & 2.6 & 2.82 & 2.24 \\
SFA & 19.93 & 26.04 & 22.03 & 20.67 \\
MUFA & 38.79 & 31.31 & 34.81 & 37.86 \\
PUFA & 41.28 & 42.65 & 43.16 & 41.47 \\
\hline
\end{tabular}

All values given are means of three determinations.

SFA: saturated fatty acids; MUFA: monounsaturated fatty acids; PUFA: polyunsaturated fatty acids. 
nephtoresorinol, trans-2-dihydroxycinamic acid and dihydrate quercetin. Sales and Resurreccion (2010) reported that peanut skins contain flavonoids such as epigallocatechin, epicatechin, catechin gallate and epicatechin gallate; proanthocyanidins including procyanidin B, A-type and B-type procyanidin dimers, trimers and tetramers; phenolic acids such as chlorogenic, coumaric, caffeic and ferulic acids; and the stilbene trans-resveratrol. Peanut kernels contain caffeic, ferulic, and coumaric acids (Sales and Resurreccion, 2009) and the stilbenes trans-resveratrol and its glucoside, transpiceid. Free p-coumaric acid, along with three tentatively identified esterified derivatives, was the predominant soluble polyphenolic that contributed to the antioxidant capacity of peanut kernels (Talcott et al., 2005 a).

Concerning DPPH scavenging activity, a considerable antiradical ability was found, especially in the Trabilsia peanut cultivar (IC50 = $1550 \mu \mathrm{g} / \mathrm{ml}$ ); the Massriya and Sinya cultivars had, respectively, 720 and $820 \mathrm{mg} / \mathrm{ml}$ IC50. The Chounfakhi cultivar presented the lowest value of IC50 $(550 \mu \mathrm{g} / \mathrm{ml})$.

Nuts are a good source of a wide range of bioactive compounds with health benefits. Many of the bioactive compounds that occur in nuts are associated with the oil fraction. Nuts contain tocopherols, tocotrienols, phytosterols and many different flavonoids, including isoflavones and quercetin. There is scientific evidence that health benefits are mediated by the bioactive components in the oil fraction of the nuts (Jonnala et al., 2006).

\subsection{Antibacterial activity}

Groundnut seed oil of the four varieties showed no antibacterial activity against all studied strains. This was not surprising, since no data were found in literature mentioning an antibacterial activity in fixed oil. This is probably due to the fact that fixed oil is composed almost entirely of triacylglycerols (TAG) that are structurally composed of aliphatic carbon and hydrogen chains that induce no antibacterial activity. Phytosterols, minor compounds of plant oils, constitute the major fraction of their unsaponifiables. Groundnuts showed phytosterol content varying from 900 to $3000 \mathrm{ppm}$; the most represented ones are $\beta$-sitosterol $(48 \%)$, campesterol (10\%), and stigmasterol (5\%) (Dewanto et al., 2002). We found that sterols from the Massriya oil exhibited antibacterial activities against Listeria ivanovii, Listeria inocua, Pseudomonas aeruginosa, Staphylococus aureus, Enterococcus hirae and Bacillus cereus (Table 5). For triterpenic alcohols and carbohydrates that can be considered as terpenes, antibacterial activity was not clear. This was probably due to their low concentrations. Indeed, only few strains were inhibited by these compounds.

\section{CONCLUSION}

In summary, this study revealed that Tunisian peanut seeds are a rich source of many important components that have good

\section{TABLE 3}

Total polyphenol and antioxidant activities (DPPH scavenging ability and reducing power) of Tunisian peanut cultivars (Mean values, $\mathrm{n}=3$ )

\begin{tabular}{lcc}
\hline & $\begin{array}{c}\text { Total phenolic content } \\
(\mathbf{m g} \text { GAE/g DW) }\end{array}$ & $\begin{array}{c}\text { DPPH· scavenging activity } \\
\text { (IC50 } \boldsymbol{\mu g} / \mathbf{m l})\end{array}$ \\
\hline Massriya & $1.35 \pm 0.08$ & $720 \pm 8.42$ \\
Sinya & $1.35 \pm 0.05$ & $820 \pm 5.38$ \\
Chounfakhi & $2.1 \pm 0.09$ & $550 \pm 7.23$ \\
Trabilsia & $1 \pm 0.06$ & $1550 \pm 21.47$ \\
\hline
\end{tabular}

TABLE 4

Identified phenolic compounds in peanut seed extracts analyzed by RP-HPLC

\begin{tabular}{lcccc}
\hline \multicolumn{1}{c}{ Peak Name } & \% Area Massriya & \% Area Sinya & $\begin{array}{c}\text { \% Area } \\
\text { Chounfakhi }\end{array}$ & \% Area Trabilsia \\
\hline Caffeic acid & 4 & 1.22 & 1.78 & 1.48 \\
Dihydroxyphenylacetic acid & 5.43 & 2.5 & 1.67 & ND \\
Syringic acid & 1.4 & 0.93 & 1.86 & 1.98 \\
p-Coumaric acid & 6.35 & 4.03 & 4.87 & 2.18 \\
Rutin trihydrate & 6.79 & 3.35 & 2.29 & 4.52 \\
Nephtoresorinol & 2.04 & 2.14 & 2.06 & 3.91 \\
Trans-2-dihydroxycinamic acid & ND & 2.55 & 0.8 & ND \\
Dihydrate quercetin & ND & ND & 5.4 & ND \\
\hline
\end{tabular}


TABLE 5

Antibacterial activity of sterols

\begin{tabular}{|c|c|c|c|c|}
\hline & Chounfakhi & Trabilsia & Sinya & Massriya \\
\hline $\begin{array}{l}\text { Listeria ivanovii } \\
\text { (RBL30) }\end{array}$ & - & - & + & + \\
\hline $\begin{array}{l}\text { Listeria inocua } \\
\text { (RBL29) }\end{array}$ & - & - & - & + \\
\hline $\begin{array}{l}\text { Escherichia coli } \\
\text { (ATCC25922) }\end{array}$ & - & - & - & - \\
\hline $\begin{array}{l}\text { Pseudomonas eruginosa } \\
\text { (ATCC15442) }\end{array}$ & - & - & - & + \\
\hline $\begin{array}{l}\text { Staphylococcus aureus } \\
\text { (ATCC6533) }\end{array}$ & - & - & - & + \\
\hline $\begin{array}{l}\text { Enterococcus hirae } \\
\text { (ATCC10541) }\end{array}$ & - & - & - & + \\
\hline $\begin{array}{l}\text { Bacillus subtilis } \\
(168)\end{array}$ & - & - & + & - \\
\hline $\begin{array}{l}\text { Bacillus cereus } \\
\text { (ATCC } 11778)\end{array}$ & - & - & - & + \\
\hline
\end{tabular}

(-): Inactive; (+): Inhibition diameter between 8-10 mm.

nutritional attributes and appear to have a very positive effect on human health (polyunsaturated fatty acids $\left(w_{3}\right.$ and $\left.\omega_{6}\right)$, phenolic components, antioxidant biomolecules, antibacterial activity...). The high levels of fatty acids and protein content make peanuts a healthy food for human and animal nutrition. Crude peanut seed oil has a good potential as alternative fuel, which we will use in Tunisia as a source of biodiesel as perspective for our work.

\section{REFERENCES}

ALVARENGA N, ESTEBAN A (2005) Bioactives triterpenes and related compounds from celastraceae, Stud. Nat. Prod. Chem. Volume 30, 635702.

ANDERSEN PC, HILL K, GORBET DW, BRODBECK BV (1998) Fatty acid and amino acid profiles of selected peanut cultivars and breeding lines, Journal of Food Composition and Analysis. Volume 11, pp. 100-111.

AOCS (1989) Official methods and recommended practices of the American oil chemist's society. Champaign: American Oil Chemist's Society. Method Ce-66.

AZADMARD-DAMIRCHI S, SAVAGE GP, DUTTA PC (2005) Sterol fraction in hazelnut and virgin olive oils and 4,40-dimethylsterols as possible markers for detection of adulteration of virgin olive oil. J. Am. Chem. Soc. Volume 82 (10) 717-724.

BERRY SK (1982) Fatty Acid Composition of 16 Groundnut (Arachis hypogaea, L.) Cultivars grown under Malaysian Conditions. Pertanika. Volume 5 (1), 20-24.

BEVERIDGE THJ, LI TSC, DROVER JCG (2002) Phytosterol content in American ginseng seed oil. J. Agric. Food Chem. Volume 50, (4) 744-750.

BHATTI IA, SHAHID SAM, ASI MR, MEHBOOB S (2010) Quality index of oils extracted from $\gamma$-irradiated peanuts (Arachis hypogaea L.) of the golden and bari varieties. Applied Radiation and Isotopes. Volume 68, Issue 12, 2197-2201.

BORNAT K (2006) Etude des différentes fractions lipidiques et protéiques de différentes variétés d'arachide (Arachis hypogea) cultivées en Tunisie. Projet de Fin d'Etudes. ISSBAT. Tunis.

BRADFORD MM (1976) A rapid and sensitive method for the quantification of microgram quantities of protein utilizing the principle of protein dye binding. Anal Biochem, Volume 72, 248-253.
DEWANTO V, WU X, ADOM KK, LIU RH (2002) Thermal processing enhances the nutritional value of tomatoes by increasing total antioxidant activity. J. Agric. Food Chem. Volume 50, 3010-3014.

FRANCISCO ML. DL, RESURRECCION, A.V.A. (2009) Development of a reversed-phase high performance liquid chromatography (RP-HPLC) procedure for the simultaneous determination of phenolic compounds in peanut skin extracts. Food Chemistry, Volume 117, Issue 2, 356-363.

FRANCISCO ML. DL, RESURRECCION, A.V.A. (201) Antioxidant capacity and sensory profiles of peanut skin infusions. LWT - Food Science and Technology, Volume 47, Issue 1, 189-198.

HAN J, BOURGEOIS S, LACROIX M (2009) Protein-based coatings on peanut to minimise oil migration, Food Chemistry 115, pp. 462-468.

HANATO T, KAGAWA H, YASUHARA T, OKUDA T (1988) Two new flavonoids and other constituents in licorice root: their relative astringency and radical scavenging effects, Chem. Pharm. Bull. Volume 36, 2090-2097.

HARWOOD HJ (1984) Oleochemicals as a fuel: Mechanical and economic feasability, J. Am. Oil Chem. Soc. Volume 61, 315-324.

HERNÁNDEZ-DÍAZ G, ALEXANDER-AGUILERA A, ARZABA-VILLALBA A, SOTO-RODRÍGUEZ I, GARCÍA HS (2010) Effect of conjugated linoleic acid on body fat, tumor necrosis factor alpha and resistin secretion in spontaneously hypertensive rats. Prostaglandins, Leukotrienes and Essential Fatty Acids. Volume 82, 105-109.

INGALE S, SHRIVASTAVA SK (2011) Nutritional study of new variety of groundnut (Arachis hypogaea L.) JL-24 seeds. African Journal of Food Science Volume 5 (8), pp. 490-498.

JONNALA RS, DUNFORD NT, DASHIE KE (2006) Tocopherol, phytosterol and phospholipid compositions of new high oleic peanut cultivars. Journal of Food Composition and Analysis. Volume 19, 601-605.

KAYA C, HAMAMCI C, BAYSAL A, AKBA O, ERDOGAN S, SAYDUT A (2009) Methyl ester of peanut (Arachis hypogea L.) seed oil as a potential feedstock for biodiesel production. Renewable Energy. Volume 34, 12571260.

KRISHNAPPA N, NARAYANASWAMY S, SREERAMA R (1999) Role of packaging material on storage mycoflora in groundnut (Arachis hypogea L.) seeds, Curr. Res., University of Agricultural Sciences (Bangalore) Volume 28, 132-135.

LAEMMLI UK (1970) Cleavage of structural proteins during the assembly for the head of bacteriophage T4. Nature. 277: 680 .

LAGARDA MJ, LIATAS GC, FARRÉ R (2006) Analysis of phytosterols in foods. J. Pharm. Biomed. Anal. Volume 411, 1486-1496.

LECHEVALLIER D (1966) Les lipides des frondes de Spirodela polyrrhiza, C. R. Acad. Sci. Paris, Ser. D. Volume 263, 1849-1852. 
LIU Y, ZHAO G, ZHAO M, REN J, YANG B (2012) Improvement of functional properties of peanut protein isolate by conjugation with dextran through Maillard reaction. Food Chemistry. Volume 131, 901-906.

METCALFE D, SCHMITZ AA, PELKA JR (1966) Rapid preparation of fattyacid esters from lipids for gas chromatographic analysis. Anal. Chem. Volume 38, 524-535.

MOREAU RA, WHITAKER BD, HICKS KB (2002) Phytosterols, phytostanols, and their conjugates in foods: structural diversity, quantitative analysis, and healthpromoting uses, Prog. Lipid Res. Volume 41, 457-500.

NAKAI VK, ROCHA LO, GONÇALEZ E, FONSECA H, ORTEGA, EMM, CORREAA B (2008) Distribution of fungi and aflatoxins in a stored peanut variety. Food Chemistry. Volume 106, pp. 285-290.

PÉREZ, RM, ÁVILA JG, PÉREZ S (1990) Antimicrobial Activity of some American Algae Journal of Ethnopharmacology. Volume 29, 1:111-116.

PLESSIS KD, STEIMAN H (2004) Practical aspects of adverse reaction to peanut. Curr. Allergy Clin. Immunol. Volume 17 (1), pp. 10-14.

PRZYBYLSKI R, ESKIN NAM (2006) Minor components and the stability of vegetable oils, Inform 17 187-189

QIU J, LEILEI C, QINGJUN Z, DAIJIE W, WENLIANG W, XIN S, XIAOYONG L, FANGLING D (2012) Screening Natural Antioxidants in Peanut shell Using DPPH-HPLC-DAD-TOF/MS methods. Food Chemistry, Volume 135, 2366-2371.

RODRÍGUES AC, STRÖHER GL, FREITAS AR, VISENTAINER JV, OLIVEIRA CC, DE SOUZA NE (2011) The effect of genotype and roasting on the fatty acid composition of peanuts.

SALES MJ, RESURRECCION, A.V.A. (2009) Maximizing resveratrol and piceid contents in UV and ultrasound treated peanuts. Food Chemistry. Volume 117, 674-680.
SALES JM, RESURRECCION, A.V.A. (2010) Phenolic profile, antioxidants, and sensory acceptance of bioactive-enhanced peanuts using ultrasound and UV. Food Chemistry. Volume 122, 795-803.

SCHIRACK AV, DRAKE M, SANDERS TH, SANDEEP KP (2006) Impact of microwave blancing on the flavour of roasted peanuts, J. Food Sci. Volume 71 (9) pp. 513-520.

SEBEI,K, DEBEZ A, HERCHI W, BOUKHCHINA S, KALLEL H (2007) Germination kinetics and seed reserve mobilization in two flax (Linum usitatissimum L.) cultivars under moderate salt stress. Journal of Plant Biology. Volume 50, Number 4, 447-454.

SEBEI K, BOUKHCHINA S, KALLEL H (2007) Évolution des tocophérols en relation avec les acides gras insaturés au cours de la maturation des graines de colza de printemps (Brassica napus L.). C. R. Biologies. Volume 330, 55-6.

SEBEI K (2005) Etude Par Couplage CGL-SM des fractions glycéridiques et non glycéridiques au cours de la lipogenèse des graines de colza (Brassica Napus L).Thèse doctorat en biologie. Faculté Des Sciences de Tunis, $220 \mathrm{p}$.

TALCOTT ST, DUNCAN EC, DEL POZO-INSFRAN D, GORBET DW (2005a) Polyphenolic and antioxidant changes during storage of normal, mid, and high oleic acid peanuts. Food Chemistry. Volume 89, 77-84.

YOSHIDA H, HIRAKAW Y, TOMIYAMAA Y, NAGAMIZU T, MIZUSHINA Y (2005) Fatty acid distributions of triacylglycerols and phospholipids in peanut seeds (Arachis hypogaea L.) following microwave treatment. Journal of Food Composition and Analysis. Volume 18, 3-14.

YOSHIDA H, SHIGEZAKI J, TAKAGI S, KAJIMOTO G (1995) Variations in the composition of various acyl lipids, tocopherols and lignans in sesame seed oils roasted in a microwave oven. Journal of the Science of Food and Agriculture. Volume 68, 407-415. 
